\title{
Macroscopic description of thoracic member musculature in Cuniculus paca (Linnaeus, 1766) (Rodentia, Cuniculidae)
}

\author{
Rodrigo Gomes de Souza ${ }^{1}$ \\ Joelma de Faria Santos ${ }^{1}$ \\ Ana Paula de Aguiar Pires ${ }^{1}$ \\ Luciana dos Santos Medeiros ${ }^{2}$ \\ Vânia Maria França Ribeiro ${ }^{2}$ \\ Yuri Karaccas de Carvalho ${ }^{2 *}$ \\ Universidade Federal do Acre \\ ${ }^{1}$ Curso de Graduação em Medicina Veterinária \\ ${ }^{2}$ Centro de Ciências Biológicas e da Natureza \\ BR 364, Km 04, Distrito Industrial, CEP 69.920-900, Rio Branco - AC, Brasil \\ * Autor para correspondência \\ yurikaracas@yahoo.com.br
}

Submetido em 12/11/2016

Aceito para publicação em 17/04/2017

\section{Resumo}

Descrição macroscópica da musculatura do membro torácico de paca (Cuniculus paca) (Linnaeus, 1766). A paca (Cuniculus paca) é um animal que pertence ao Filo Chordata, Classe Mammalia e Família Cuniculidae. A grande demanda pela carne desse animal levou à sua domesticação e ao desenvolvimento de criatórios na região Amazônica e em outros estados do país. Apesar do crescente consumo da carne de paca, o conhecimento sobre a musculatura ainda é escasso. A descrição anatômica dos membros torácicos da paca dará subsidio para futuros estudos zootécnicos e veterinários, possibilitando o desenvolvimento amazônico concomitante à preservação da espécie. Para o presente estudo, foram utilizadas quatro pacas adultas, provenientes do Projeto Caboclinho da Fazenda Experimental Catuaba/UFAC, sob a autorização IBAMA no 509309, fixadas em solução de formol a $10 \%$. Após dissecação do membro torácico dos animais, foi realizada a descrição anatômica com o subsequente registro fotográfico. Os músculos descritos do membro torácico são semelhantes a outros grupos de animais domésticos, quanto à origem e à inserção muscular.

Palavras-chave: Anatomia; Musculatura torácica; Músculos; Roedores

\section{Abstract}

Cuniculus paca (Mammalia: Cuniculidae), or "paca" is a rodent species in great demand for its meat, which has led to domestication and development of paca farms in the Brazilian Amazon region, as well as in other states. Despite the growing consumption of paca meat, knowledge on muscle anatomy is still scarce. An anatomical description of paca forelimbs will form the basis for future zootechnical and veterinary studies, enabling the development of sustainable production in the Amazon region, as well as the preservation of the species. We 
studied forelimb anatomy in four (04) adult pacas from the Caboclinho Project of Catuaba Experimental Farm (UFAC) under IBAMA authorization no 509309. Specimens were fixed in 10\% formalin and thoracic limbs were dissected, after which anatomical descriptions and photographic records were generated. We found that paca forelimb musculature is similar to that of other groups of domestic animals with regard to the origin and muscle insertion.

Key words: Anatomy; Muscles; Rodents; Thoracic limb.

\section{Introduction}

The number of described species in the class Mammalia is approaching 4,809 worldwide. Brazil hosts the greatest diversity with 524 described species, corresponding to $11 \%$ of the total mammal species (CÂMARA; MURTA, 2003). Rodents are more numerous and populations more abundant in South America when compared to other continents, where they represent approximately $44 \%$ of all wild mammals. The number of mammals, birds and reptiles consumed annually through subsistence hunting in the Brazilian Amazon is estimated to be between 9.6 and 23.5 million animals, and 62,808 tons of meat. Although some tropical forest areas seem to be relatively intact, anthropogenic effects have already caused the extinction of several animal species, where human activities affect wildlife either indirectly (e.g., habitat reduction) or directly (e.g., hunting) (REDFORD, 1997; LOPES; FERRARI, 2000; PRIMACK; RODRIGUES, 2001; ROSSER; MAINKA, 2002; JEROZOLIMSKI; PERES, 2003).

In order to strengthen programs for sustainable consumption of animal protein in the Amazon region, captive breeding of wild species has been proposed. This is considered an admissible proposal mainly for the species most commonly consumed in the regional community (CAMPO-ROZO; ULLOA, 2003).

One of the domesticated paca species is Cuniculus paca (Cuniculidae) (WOODS; KILPATRICK, 2005), as there is high demand for its meat (SMYTHE, 1987; SMYTHE; BROWN DE LA GUANTI, 1995; RENGIFO et al., 1996). Despite being a common animal among the inhabitants of Amazonian communities, knowledge of the muscle anatomy in this species is still scarce. Further, information that may aid in animal husbandry is scarce for animals in captivity in zoos and Brazilian farms, and this lack of knowledge directly influences the viability of sustainable production.

\section{Materials and Methods}

This study was held at the Federal University of Acre (UFAC) in the Animal Anatomy Laboratory. We analyzed musculature in four adult Cuniculus paca from the Projeto Caboclinho da Fazenda Experimental Catuaba, each with body mass around $2-3 \mathrm{~kg}$. The study was authorized by the Brazilian Institute of Environment and Renewable Natural Resources (IBAMA) permit $\mathrm{n}$ o 509309. The acquired animals died naturally. Specimens were first thawed in running water and then fixed with an 10\% aqueous formaldehyde solution through left femoral artery cannulation and intramuscular and intracavitary infusion. After this procedure, the animals were placed in plastic boxes containing the same fixative solution for seven days. The specimens were then dissected following conventional techniques. The skin was removed and then the forelimb muscles were dissected, after which we performed macroscopic analysis and photo documentation. The muscle morphology was described following the International Committee on Veterinary Gross Anatomical Nomenclature (2012).

\section{Results}

The gross anatomy of $C$. paca forelimb muscles was described in two portions: the musculature of the arm and forearm, each in medial and lateral view. Identifications were also based on regions of muscle origin and insertion.

The scapular and arm region musculature in the lateral view were as follows: supraspinatus, infraspinatus, teres minor, deltoideus, biceps, brachialis, triceps 
brachii caput laterale, triceps brachii caput longum, and anconeus (Figure 1A). In the forearm region lateral view, we identified the following muscles: extensor carpi radialis, extensor digitorum (digitalis) communis, extensor digitorium (digitalis) lateralis, extensor carpi ulnaris, flexor carpi ulnaris caput humerale, flexor carpi ulnaris caput ulnare, and abductor digiti I (pollicis) longus (Figure 1B).

The following musculature was visible in the scapular and arm region in medial view: pectoralis minor, supraspinatus, subscapularis, teres major, coracobrachialis, clavicular, biceps brachii, triceps brachii caput mediale, triceps brachii caput acessorium, triceps brachii caput longum and tensor fasciae antebrachiia (Figure 2A). In the forearm region in medial view, the following muscles were observed: extensor carpi radialis, pronator teres, flexor carpi radialis, flexor digitorum (digitalis) superficialis, flexor carpi ulnaris, flexor digitorum (digitalis) profundus caput radiale and flexor digitorum (digitalis) profundus caput humerale (Figure 2B).

FIGURE 1: (A) Photomacrograph of C. paca scapular and arm region in lateral view. 1 - Supraspinatus muscle; 2 - Infraspinatus muscle; 3 - Teres minor muscle; 4 - Deltoideus muscle; 5 - Biceps brachii muscle; 6 - Brachialis muscle; 7 - Triceps brachii caput laterale muscle; 8 - Triceps brachii caput longum muscle; 9 - Anconeus muscle. (B) Photomacrograph of the forearm region in side view. 1 - Extensor carpi radialis muscle; 2 - Extensor digitorum communis muscle; 3 - Extensor digitorium lateralis muscle; 4 - Extensor carpi ulnaris muscle; 5 - Flexor carpi ulnaris caput humerale muscle; 5' - Flexor carpi ulnaris caput ulnare muscle; 6 - Abductor digiti I longus muscle.
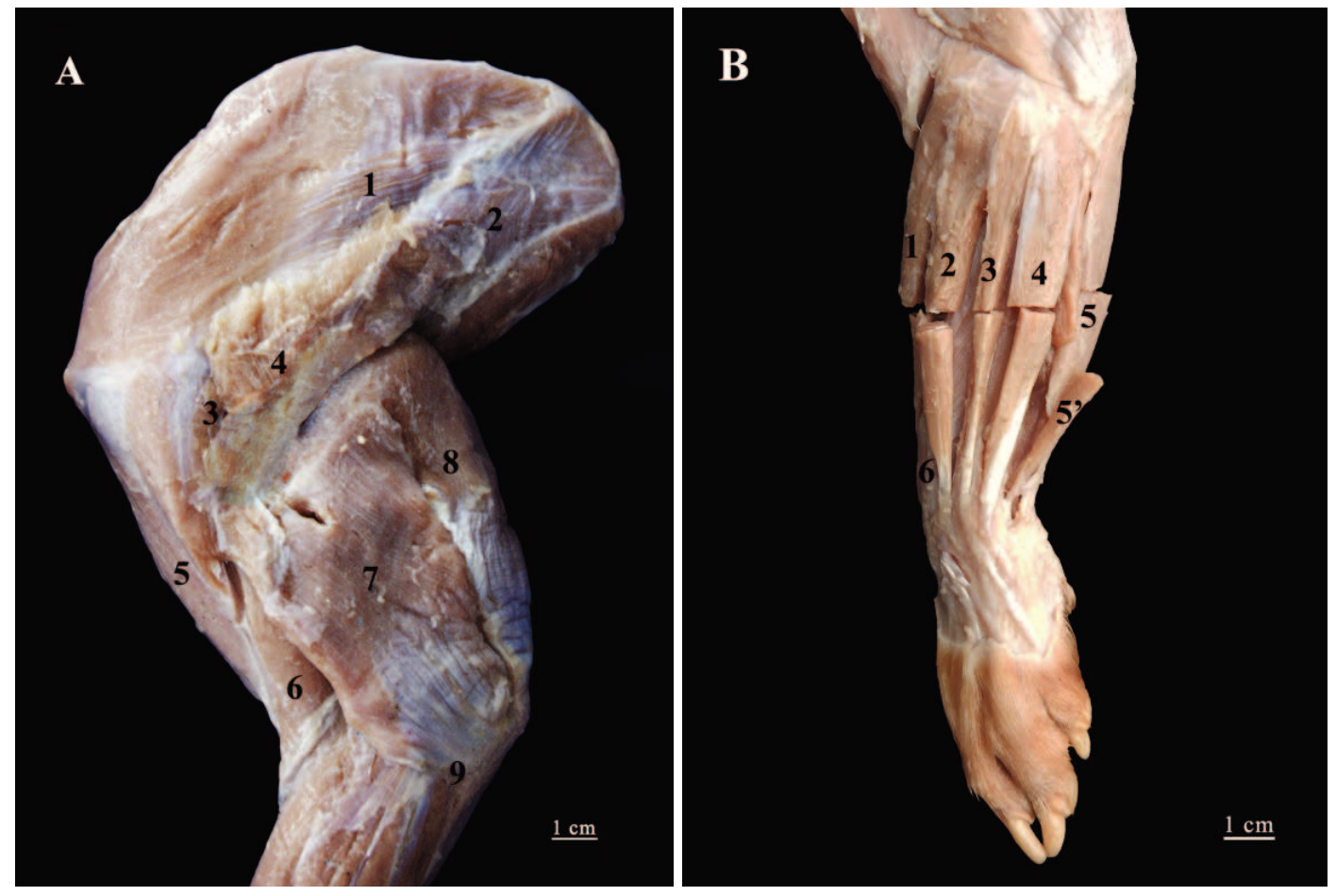
FIGURE 2: (A) Photomacrograph of C. paca scapular and arm region in medial view. 1 - Pectoralis minor muscle; 2 - Supraspinatus muscle; 3 - Subscapularis muscle; 4 - Teres major muscle; 5 - Coracobrachialis muscle; 6 - Clavicular muscle; 7 - Biceps brachii muscle; 8 - Triceps brachii caput mediale muscle; 9 - Triceps brachii caput acessorium muscle; 10 - Triceps brachii caput longum muscle; 11 - Tensor fasciae antebrachii muscle. *Clavicle. (B) Photomacrograph of the forearm region in medial view. 1 - Extensor carpi radialis muscle; 2 - Pronator teres muscle; 3 - Flexor carpi radialis muscle; 4 - Flexor digitorum superficialis muscle; 5 - Flexor carpi ulnaris caput humerale muscle; 6 - Flexor digitorum profundus caput radiale muscle; 6' - Flexor digitorum profundus caput humerale muscle.
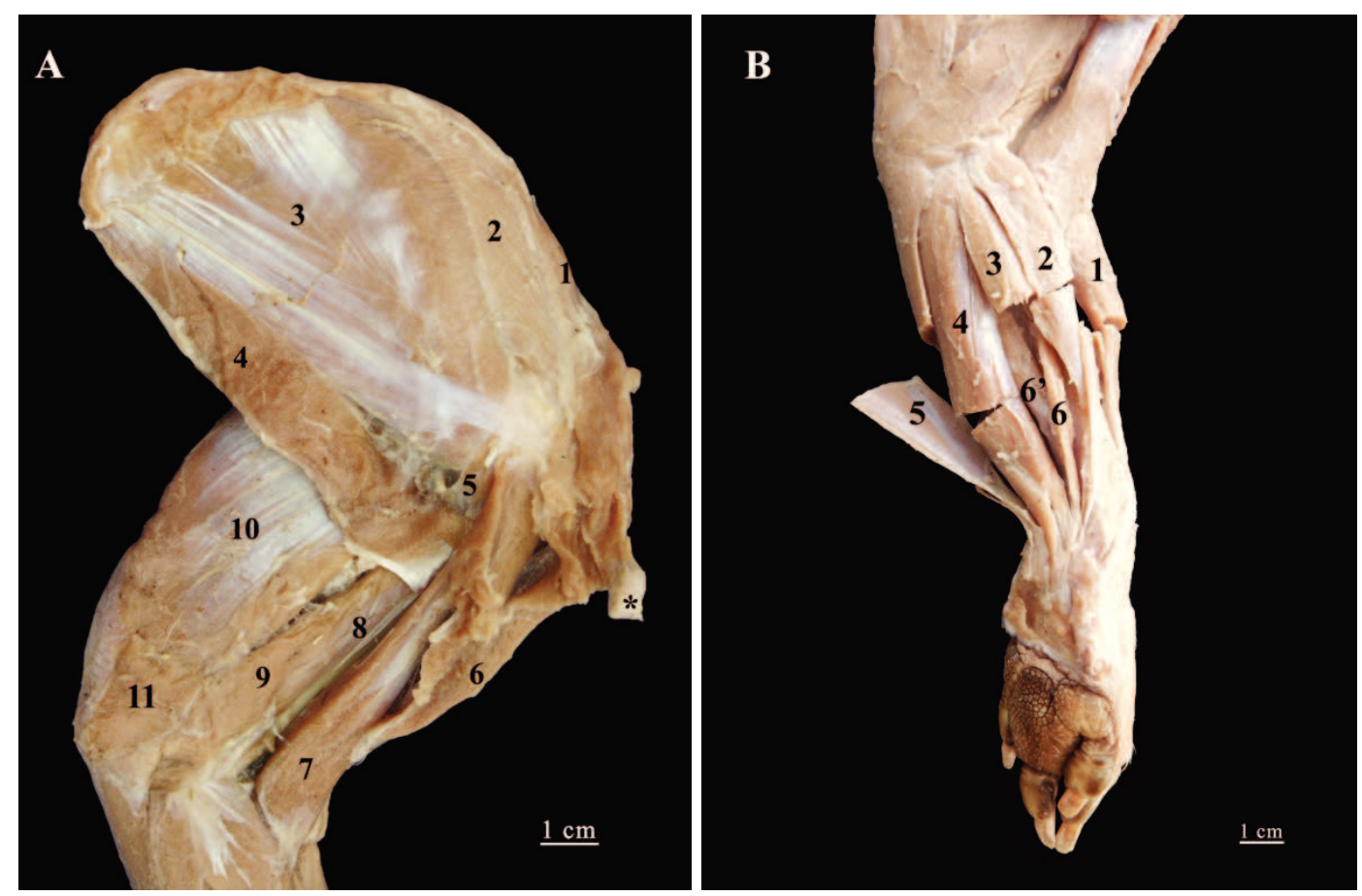

\section{Discussion}

Although there are published works describing musculature for other Cuniculus species, there were none that could be used for direct comparison with $C$. paca. Thus, the description was based on species in class Mammalia.

The forelimb muscles of Cuniculus paca have strong similarities with related structures in other mammals, such as the domestic dog (Canis familiaris) (GETTY et al., 1986; SCHALER, 1999; DYCE et al., 2010; KÖNIG; LIEBICH, 2011; POPESKO, 2012) and bush dogs (Cerdocyon thous) (RODRIGUES et al., 2013), the coati (Nasua nasua) (SANTOS et al., 2010), and the crab-eating raccoon (Procyon cancrivorus) (SANTOS et al., 2013).

The supraspinatus muscle emerges from fossa supraspinata of the scapula and the fossa crossing cranially, as occurs in domestic (DONE et al., 2010) and bush dogs (RODRIGUES et al., 2013), coati (SANTOS et al., 2010) and crab-eating raccoon (SANTOS et al., 2013). In the distal meaning, it is located cranially to the shoulder joint and has insertion in two, strong, collarbone tendons and the cranial portion of the tuberculum majus. The supraspinatus muscle extends the shoulder joint (GETTY et al., 1986).

The infraspinatus muscle is located in the fossa infraspinata, transcending caudally, as in bush dogs (RODRIGUES et al., 2013), coati (SANTOS et al., 2010) and cougar (CONCHA et al., 2004). It arises from the fossa infraspinata and spine scapulae, and crosses above the lateral view of the shoulder joint, which becomes a strong tendon. It is covered proximally by the deltoideus muscle. Getty et al. (1986) show that the infraspinatus muscle acts primarily as a lateral collateral ligament of the shoulder joint.

The deltoideus muscle is fixed directly and inferiorly to the skin, and elongates between the scapula 
and the tuberositas deltoidea of the humerus. In paca, the deltoideus muscle has two heads that appear to begin the spine of the scapulae, and a large bone structure that performs a function similar to the acromion, which described in coati (SANTOS et al., 2010), as well as in ruminants and carnivores (DYCE et al., 2010). Schaler (1999) reported that in horses the two heads are connected, which is due to the absence of the acromion on the scapula. The two heads of the deltoideus muscle act synergistically in flexion and lateral rotation of the humerus.

The teres minor muscle in paca, as in bush dogs (RODRIGUES et al., 2013) and coati (SANTOS et al., 2010), has a small and triangular shape and is located caudally to shoulder, the tuberculum infraglenoidale and the distal third of caudal margin of the scapula is its origin, inserting in the tuberositas teres minor of the humerus. Santos et al. (2010) proposed that this muscle function is to flex the shoulder and laterally rotate the arm.

The biceps brachii muscle in paca is similar to that seen in domestic (DYCE et al., 2010) and bush dogs (RODRIGUES et al., 2013), coati (SANTOS et al., 2010), and crab-eating raccoon (SANTOS et al., 2013). This muscle is at cranio-medial surface of the humerus. It arises near a tendon above the tuberculum supraglenoidale. At the height of the elbow joint the muscle opens into two branches. The more compact of the two is introduced into the tuberositas radii, and the other at the proximal ulna. König and Liebich (2011) note that in carnivores, the biceps brachii muscle bends within the capsule of the shoulder joint anteriorly, forming a synovial sheath in the intertubercular sulcus, diverging in paca, in which it is not attached to the sheath. Evans and de Lahunta (2001) suggested that this muscle flexes the forearm in synergy with the brachial muscle, promoting extension of the shoulder joint and acting as a stabilizer.

Beginning on the caudal face of the proximal humerus, peripheral to the humeral neck, the paca brachii muscle is inserted in the tuberositas radii and ulnae, similar to what is described in crab-eating raccoons (SANTOS et al., 2013), cougars (CONCHA et al., 2004), dogs and cats (SCHALER, 1999). The size of this muscle differs in the paca from that observed in coati by Santos et al. (2010), and the higher muscular venter volume is likely due to the climbing habits of these animals.

The triceps brachii muscle in paca is equivalent to that of domestic dogs in form and function, as outlined by Popesko (2012). This muscle is large, consisting of three heads and a caput acessorium which originate from different locations, but with a common insertion. The caput longum emerges near the tuberculum supraglenoidale of the axillary border of the scapula; the caput laterale of the tuberositas deltoidea from the lateral side of the humerus, and the caput mediale from the medial side of the humerus body. The caput accessorium in paca, as in the tapir (Tapirus terrestris) (PEREIRA et al., 2015), originates from the caudal part of the humeral neck, joining the caput longum and caput laterale. The caput longum is the largest and longest, and the caput mediale the lowest. The triceps brachii muscle flexes and becomes stable at the elbow joint.

The anconeus muscle is small and triangular, and is located under the triceps brachii muscle in the caudal aspect of the lateral surface of the elbow. In paca, as in as in bush dogs (RODRIGUES et al., 2013), the function of this muscle is to extend the elbow joint

The extensor carpi radialis muscle is the largest extensor muscle of the carpal joints. This is a thin muscle in which the bulk of the mass constitutes the region from the radial antimere of the deep forearm to the brachioradialis muscle. It emerges from the lateral epicondyle of the humerus and the lateral epicondylar crest, and it is part of the proximal end of the first metacarpal bone, in contrast to what was reported in the coati by Santos et al. (2010). The extensor carpi radialis muscle extends and determines the carpal joint (GETTY et al., 1986).

The extensor digitorum communis muscle in paca is firm and strong with various tendon intersections, and is attached to the extensor carpi radialis muscle. It emerges from the lateral epicondyle of the humerus in paca, as in crab-eating raccoon (SANTOS et al., 2013). The muscular venter becomes three tendons, formed by five parts joining together, which is equivalent to the number of functional fingers. The tendon extends 
downwardly within the lateral sulcus of the radius and superior to the extending surface of the carpus. These findings contrast what has been described in other domestic animals (DONE et al., 2010), and in wild animals like the coati (SANTOS et al., 2010) and cougar (CONCHA et al., 2004).

Next to the extensor digitorum communis muscle and caudal in position, the extensor digitorum lateralis muscle in paca emerges from lateral collateral ligament of the elbow joint, with lateral tuberosity at the proximal edge of the radius and the lateral view of the ulna. The extensor digitorum lateralis muscle is introduced through two tendons in the fourth and fifth digits. It is divided into two muscular venters and allows extension of the digital joints, as described in domestic animals (KÖNIG; LIEBICH, 2011).

The extensor carpi ulnaris muscle is located in caudolateral antimere of the forearm. In paca it is similar to what has been described for coati (SANTOS et al., 2010), cougars (CONCHA et al., 2004), crab-eating raccoons (SANTOS et al., 2013), and carnivores (DONE et al., 2010). It stretches up through the lateral epicondyle of the humerus, and the lateral carpal and metacarpal bones. The tendon is wide and firm, becomes prominent soon after the other extensor muscles of the group. The extensor carpi ulnaris muscle is inserted through a tendon at the fifth digit. It performs the flexor function of carpal joint (EVANS; De LAHUNTA, 2001).

The pectoralis minor muscle found in the craniomedial region of the scapula in paca, as in rabbits (POPESKO, 2012), and arises from the cranial angle of the scapula introducing the clavicle.

The subscapularis muscle of paca, as in coati (SANTOS et al., 2010), is a vast and flattened muscle occupying the fossa of the same name, which it transcends cranial and caudally. The fibers of the various bundles converge at the apex of the scapula and the tuberculum minus of the humerus. In bush dogs this muscle is well developed (RODRIGUES et al., 2013), however that is not the case in paca.

Beginning at collarbone, the clavicle muscle inserts along the humerus crest, as reported by Popesko (2012) in rabbits. This muscle has the task of assisting in shoulder stabilization.
In paca, as in bush dogs (RODRIGUES et al., 2013) and coati (SANTOS et al., 2010), the teres major muscle is a large muscle that covers the axillary border of scapula, extending to the flexor side of the shoulder joint and the the end of the greater tuberosity, serving to flex and rotate the muscle medially.

The coracobrachialis muscle in paca is small, similar that seen in bush dogs (RODRIGUES et al., 2013). It is located on the medial side of the shoulder joint, originating from the processus coracoideus of the scapula, having as insertion the smaller tubercle of the humerus, proximal to the larger round tuberosity. According to Evans and de Lahunta (2001) this muscle raises and extends the shoulder.

The pronator teres muscle in paca, as in crab-eating raccoon (SANTOS et al., 2013), is obliquely oriented throughout the cranial extension of the forearm. It originates from the medial epicondyle of the humerus, and is set in the middle third of the medial end of the radius.

The flexor carpi radialis muscle is located in the medial antimere of forearm, caudal to the margin of the radius. In paca, the flexor carpi radialis muscle arises from the medial epicondyle of the humerus and is fixed on the palmar aspect of the first metacarpal bone. These data contrast descriptions of the coati (SANTOS et al., 2010), cougar (CONCHA et al., 2004) and crab-eating raccoon (SANTOS et al., 2013).

In agreement with that described by König and Liebich (2011) for domestic animals, the flexor digitorum profundus muscle is the most internal and thickest muscle of the caudal set. This muscle runs beneath the flexor digitorum superficialis muscle and the flexor carpi muscles in the caudal portion of forearm (DYCE et al., 2010; POPESKO, 2012). It has two heads, the caput humerale and the caput radiale, which are associated with the carpus to form the flexor digitorum profundus tendon, diverging in the cougar to form three heads (CONCHA et al., 2004). This tendon follows five tendons in paca, equivalent to that reported by König and Liebich (2011) for carnivores. In this species, the flexor digitorum tendon of the fingers results in five tendons; the number of tendons comprising the flexor digitorum profundus muscle is analogous to the number of the 
corresponding extensor muscle tendons in the extensor digitorum communis muscle. Schaler (1999) states that its function is bending the carpus and distal phalanx of the main fingers.

The flexor carpi ulnaris muscle in paca exhibits the same morphology as in the coati (SANTOS et al., 2010) and cougar (CONCHA et al., 2004). It is composed of two parts: the smaller caudal portion, called the ulnar portion, emerges from the olecranon; the larger humeral portion arises from the medial epicondyle of the humerus. Both portions end with a common tendon with insertion in the carpi acessorium bone. The flexor carpi ulnaris acts in carpus joint flexion.

The abductor digiti I longus muscle in paca, as in dogs (KÖNIG; LIEBICH, 2011), lies in the sulcus region between the radius and ulna. This muscle originates from the lateral margin and cranial surface of the ulna body, and is part of the proximal end of the first metacarpal. Evans and de Lahunta (2001) describe that the abductor muscle of the first finger has the task of abducting the first finger.

The tensor fasciae antebrachii muscle of the paca is located on the medial side of the triceps brachii muscle, as in coati (SANTOS et al., 2010), cougars (CONCHA et al., 2004), and carnivores (GETTY et al., 1986). It originates in an extensive aponeurosis of the latissimus dorsi muscle and inserts in the forearm fascia. The tensor fasciae antibrachii muscle has the function of flexion the shoulder joint, tension in the fascia antebrachii, and extension of the elbow joint.

The results of this study suggest that paca forelimb musculature is similar to that of other groups of domestic animals with respect to origin and muscle insertion, which is expected among terrestrial animals. The description supplied here should provide valuable information for future husbandry and veterinary studies, potentially enabling the development of sustainable farming practices and species conservation in the Amazon region.

\section{References}

CÂMARA, T.; MURTA, R. Mamíferos da Serra do Cipó. Belo Horizonte: PUC-Minas/Museu de Ciências Naturais, 2003. 129 p.
CAMPO-ROZO, C.; ULLOA, A. Perspectivas y tendencias en torno al manejo de fauna participativo en América Latina. In: CAMPOROZO, C.; ULlOA, A. (Ed.). Fauna socializada: tendencias en el manejo participativo de la fauna en América Latina. Bogotá: Fundación Natura, MacArthur Foundation, Instituto Colombiano de Antropologia e História, 2003. p. 27-50.

CONCHA, I.; ADARO, L.; BORRONI, C.; ALTAMIRANO, C. Consideraciones anatómicas sobre la musculatura intrínseca del miembro torácico del puma (Puma concolor). International Journal of Morphology, Temuco, v. 22, n. 2, p. 121-125, 2004.

DONE, S. H.; GOODY, P. C.; EVANS, S. A.; STICKLAND, N. C. Atlas colorido de anatomia veterinária do cão e gato. 2 . ed. Rio de Janeiro: Elsevier, 2010. 544 p.

DYCE, K. M.; SACK, W. O.; WENSING, C. J. G. Tratado de anatomia veterinária. 4. ed. Rio de Janeiro: Elsevier, 2010. 856 p.

EVANS, H. E.; de LAHUNTA, A. Guia para a dissecção do cão. 5. ed. Rio de Janeiro: Guanabara Koogan, 2001. 250 p.

GETTY, R.; SISSON, S.; GROSSMAN J. D. Anatomia dos animais domésticos. Vol. 2. 5. ed. Rio de Janeiro: Guanabara Koogan, 1986. 2048 p.

INTERNATIONAL COMMITTEE ON VETERINARY GROSS ANATOMICAL NOMENCLATURE. Nomina anatômica veterinária. 5. ed. Knoxville: World Association on Veterinary Anatomist, 2012. $177 \mathrm{p}$.

JEROZOLIMSKI, A.; PERES, C. A. Bringing home the biggest bacon: a cross-site analysis of the structure of hunter-kill profiles in Neotropical forests. Biological Conservation, Boston, v. 111, n. 3, p. 415-425, 2003.

KÖNIG, H. E.; LIEBICH, H. G. Anatomia dos animais domésticos. Texto e atlas colorido. 4. ed. Porto Alegre: Artmed, 2011. 787 p.

LOPES, M. A. E.; FERRARI, S. F. Effects of human colonization on the abundance and diversity of mammals in eastern Brazilian Amazonia. Conservation Biology, San Francisco, v. 14, n. 6, p. 1658-1665, 2000.

PEREIRA, S. G.; SANTOS, A. L. Q.; BORGES, D. C. S.; SOUZA, R. R. de; QUAIOZ, P. R. Anatomia óssea e muscular do cíngulo escapular e braço de Tapirus terrestres (Perissodactyla: Tapiridae). Ciência Animal Brasileira, Goiânia, v. 16, n. 2, p. 268-278, 2015. POPESKO, P. Atlas de anatomia topográfica dos animais domésticos. 5. ed. São Paulo: Manole, 2012. 608 p.

PRIMACK, R. B.; RODRIGUES, E. Biologia da conservação. 1. ed. Londrina: E. Rodrigues, 2001. 328 p.

REDFORD, K. H. A floresta vazia. In: VALLADARES-PADUA, C.; BODMER, R. E.; CULLEN JR, L. (Ed.). Manejo e conservação de vida silvestre no Brasil. Brasília: MCT-Cnpq/Sociedade Civil Mamirauá, 1997. p. 1-22.

RENGIFO, M. E.; NAVARRO, D. T.; URRUNAGA, A. B.; VÁSQUEZ, W. F.; ASPAJO, F. V. Crianza familiar del majaz o paca (Agouti paca) en la Amazonia. Lima: Tratado de Cooperacion Amazonica-Secretaria pró tempore 48, 1996. 43 p.

RODRIGUES, R. G. A.; GOMES, A. V.; BIRCK, A. J.; FILADELPHO, A. L. Descrição dos músculos do ombro e braço do cachorro do mato (Cerdocyon thous). Revista Científica Eletrônica de Medicina Veterinária, Garça, Ano XI, n. 21, s/ paginação, 2013. 
ROSSER, A. M. E.; MAINKA, S. A. Overexploitation and species extinctions. Conservation Biology, San Francisco, v. 16, n. 3, p. 584-586, 2002.

SANTOS, A. C. dos; BERTASSOLI, B. M.; OLIVEIRA, V. C de; CARVALHO, A. F.A de; ROSA, R. A.; MANÇANARES, C. A. F. Morfologia dos músculos do ombro, braço e antebraço do quati (Nasua nasua Linnaeus, 1758). Biotemas, Florianópolis, v. 23, n. 3, p.167-173, 2010.

SANTOS,A. C. dos; BERTASSOLI, B.; ROSA, R. A.; CARVALHO, A. F. de; MANÇANARES, C. A. F. Miologia comparada do membro torácico do mão-pelada (Procyon cancrivorus, G. Cuvier, 1798). Revista da FZVA, Uruguaiana, v. 17, n. 2, v. 262-275, 2013. SCHALER, O. Nomenclatura anatômica veterinária ilustrada. São Paulo: Manole, 1999. 576 p.
SMYTHE, N. The paca (Cuniculus paca) as a domestic source of protein for the Neotropical, humid lowlands. Applied Animal Behaviour Science, Amsterdam, v. 17, p. 155-170, 1987.

SMYTHE, N.; BROWN DE LA GUANTI, O. La domesticación de la paca (Agouti paca). Guia FAO de Conservación 26. Roma: FAO, 1995. 95 p.

WOODS, C. A.; KILPATRICK, C. W. Infraorder Hystricognathi. In: WILSON, D. E.; REEDER, D. M. (Ed.). Mammal species of the world: a taxonomic and geographic reference. Vol. 2, 3. ed. Baltimore: John Hopkins University Press. 2005. p. 1538-1600. 